\title{
PENGGUNAAN INDOLE-3-BUTYRIC ACID (IBA) UNTUK MENINGKATKAN PERTUMBUHAN STEK BATANG KOPI ROBUSTA
}

\author{
Used of Indole-3-Butyric Acid (IBA) to Improve Growth of Robusta Coffee Cuttings
}

Bistok Hasiholan Simanjuntak* dan Ratna Dewi P

\author{
Fakultas Pertanian dan Bisnis, Universitas Kristen Satya Wacana, Salatiga \\ J1. Diponegoro 66 Salatiga - Indonesia 50711
}

Alamat korespondensi: bhasiholans@yahoo.com

\begin{abstract}
ABSTRAK
Perbanyakan kopi robusta (Coffea canephora) dengan metode stek sering terkendala pada pertumbuhan akar dan tunas daun. Pemberian Indole-3-Butyric Acid (IBA) diharapkan dapat mengatasi masalah pertumbuhan akar dan tunas pada stek batang. Tujuan penelitian ini adalah untuk menemukan konsentrasi IBA yang tepat terhadap pertumbuhan akar dan tunas daun stek kopi robusta. Penelitian ini menggunakan Rancangan Acak Kelompok (RAK) nonfaktorial dengan perlakuan konsentrasi IBA terdiri atas 0 ppm, 50 ppm, 100 ppm, 150 ppm, 200 ppm, 250 ppm, dan 300 ppm, dan diulang 4 kali. Parameter pengamatan meliputi panjang akar, jumlah daun, bobot basah dan kering berangkasan stek batang. Hasil penelitian menunjukkan bahwa pemberian IBA 150 ppm pada stek batang kopi robusta mampu menghasilkan panjang akar terbaik. Namun demikian, seluruh konsentrasi IBA yang diujikan belum mampu meningkatkan jumlah daun, berat berangkasan basah, dan berat berangkasan kering stek batang kopi robusta.
\end{abstract}

Kata kunci: Indole Butyric Acid, kopi robusta, stek batang,

\section{ABSTRACT}

Coffee Robusta (Coffea canephora) propagation by cuttings method is often constrained by roots and leaf shoots growth. The application of Indole-3-Butyric Acid (IBA) is expected to solve the root and shoot growth problems on stem cuttings. The research objective was to determine the appropriate IBA concentration on the roots and shoots growth of coffee robusta cuttings. Randomized completed block design (RCBD) nonfactorial was applied with the IBA concentration consisted of 0 ppm, 50 ppm, 100 ppm, 150 ppm, 200 ppm, 250 ppm, and 300 ppm, and repeated 4 times. The observation parameters were root length, number of leaves, wet and dry weight of stem cuttings. The results showed that application of IBA $150 \mathrm{ppm}$ to coffee robusta stem cuttings improved root length. However, the all concentration of IBA was not increase the leaves number, and fresh and dry weight of coffee robusta stem cuttings.

Keywords: Indole-3-Butyric Acid, robusta coffee, stem cuttings.

\section{PENDAHULUAN}

Penanaman kopi di Indonesia di dominasi oleh kopi robusta (Coffea canephora) baik yang diusahakan oleh perkebunan rakyat maupun perkebunan besar milik negara atau swasta. Pada tahun 2019 luas penanaman kopi robusta di Indonesia mencapai $75 \%$ dari total luas penanaman kopi secara keseluruhan (Widaningsih, 2019). Penggunaan bahan tanam ungul akan menentukan tingkat produktivitas tanaman. Bahan tanam unggul kopi robusta dapat diperoleh dari cara perbanyakan tanaman secara generatif atau vegetatif. Pada kopi robusta, perbanyak tanaman secara generatif dalam waktu sekitar 8-9 bulan dapat dihasilkan tanaman baru yang siap tanam dalam jumlah yang banyak dan memiliki sistem perakaran yang dalam dan kuat. Akan tetapi 
untuk kopi robusta yang diperbanyak secara generatif akan dihasilkan tanaman baru yang tidak sama sifat dengan tanaman induknya. Sifat kopi robusta adalah tidak kompatibel menyerbuk sendiri (self incompatible) yang dikendalikan oleh gen tunggal dengan banyak alel sehingga cenderung terjadi serbuk silang (Syafarudin et al., 2017). Biji hasil serbuk silang jika digunakan sebagai sumber benih tanaman baru akan dihasilkan tanaman baru yang memiliki variasi sangat tinggi dari tanaman induknya (Brata et al., 2020). Oleh karena itu perbanyakan tanaman kopi robusta banyak dilakukan dengan metode vegetatif melalui sambung pucuk (tunas) atau cara stek. Perbanyakan tanaman kopi robusta dengan cara stek umum dilakukan dengan stek cabang atau batang dan akan dihasilkan tanaman baru dengan sifat sama tanaman induk (Hadiati, 2011 ; Dewi dan Susanti, 2010 ; Pandey et al., 2011). Pada tanaman kopi robusta, perbanyakan tanaman dengan cara stek umumnya dilakukan dengan tujuan untuk dihasilkan tanaman baru sebagai sumber pucuk unggul yang nantinya akan digunakan untuk perbanyakan cara sambung pucuk (tunas).

Tingkat keberhasilan tumbuh stek batang ditentukan dari keberhasilan stek membentuk akar yang diinduksi oleh keberadaan susbtansi pengatur tumbuh (Saptaji et al., 2015; Ningsih dan Rohmawati, 2019). Pembentukan akar dari stek batang merupakan proses kompleks dan dipengaruhi banyak faktor seperti genetik, fisiologi dan perkembangan pohon induk serta substansi pengatur tumbuh dan metabolisme tanaman (Geiss, 2009; Pop et al., 2011). Substansi pengatur tumbuh dalam bahan stek harus berada dalam jumlah yang cukup sehingga jika konsentrasi substansi pengatur tumbuh endogen (dalam tanaman) berada dalam konsentrasi yang kurang dapat dilakukan dengan penambahan substansi pengatur tumbuh eksogen (dari luar tanaman). Auksin adalah salah satu substansi pengatur tumbuh yang memegang peranan penting dalam menstimulir munculnya akar pada stek batang. Interaksi antara auksin dan karakteristik tanaman (genotipe tanaman) memiliki pengaruh yang signifikan terhadap keberhasilan induksi dan diferensiasi akar pada stek batang (Kesari et al., 2010).

Auksin diproduksi tanaman pada jaringan meristem, dimana auksin mampu meningkatkan persentase pembentukan akar, mempercepat inisiasi akar, meningkatkan jumlah dan kualitas akar dan mempromosikan pengembangan akar yang seragam (Blythe et al., 2007; Khasin et al., 2018; Gudeva et al., 2017). Jika auksin endogen pada stek batang berada dalam konsentrasi yang tidak mampu mempengaruhi pembentukan akar, maka pemberian auksin eksogen akan membantu 
pembentukan akar pada stek batang. Efektifitas pemberian auksin eksogen tergantung pada tingkat auksin endogen sehingga aplikasi auksin eksogen dapat bersifat promotif, tidak efektif atau bahkan menghambat pembentukan akar pada stek (Kesari et al., 2010). Oleh Skupa et al. (2014) dinyatakan bahwa tingkat keberhasilan auksin dalam mempengaruhi seluruh fase perkembangan tanaman saat membentuk akar akan ditentukan konsentrasi auksin yang ada didalam jaringan tanaman.

Indole-3-Butyric Acid (IBA) adalah substansi pengatur tumbuh luar (eksogen) dari golongan auksin mempunyai kemampuan merangsang pembentukan akar pada stek. Interaksi IBA sebagai auksin eksogen dengan auksin endogen didalam jaringan tanaman akan mempengaruhi proses metabolisme tanaman sehingga akan meningkatkan laju pembentukan akar dan jumlah akar terbentuk (Pacurar et al., 2014). Oleh Mohammad et al. (2013) dinyatakan perlakuan auksin eksogen memiliki efek positif pada rhizogenesis (pembentukan akar) stek pada konsentrasi tertentu, dan auksin eksogen yang paling stabil dan efektif dalam pembentukan akar pada stek adalah IBA. Hal ini seperti yang dinyatakan San Jose et al. (2012) bahwa penggunaan IBA mampu meningkatkan kecepatan perakaran, persentase stek berakar, jumlah dan kualitas akar per stek, serta keseragaman perakaran.

$$
\text { Penggunaan }
$$

IBA harus memperhatikan konsentrasinya, karena dengan konsentrasi yang tepat maka IBA akan sangat efektif dalam menumbuhkan akar (Akwatulira et al., 2011; Mejury et al., 2019). IBA dapat digunakan pada banyak tanaman untuk menstimulasi pembentukan akar akan tetapi faktor kosentrasi yang tepat merupakan faktor penting IBA untuk menstimulir pembentukan akar (Gilani et al., 2019; Akram et al., 2017; Li et al., 2009). Pada konsentrasi yang rendah IBA kurang efektif dalam menstimulasi pembentukan akar, namun pada konsentrasi yang tinggi juga kurang menguntungkan bagi stek karena akan meracuni jaringan tanaman sehingga akan menggagalkan pembentukan akar stek. Tampaknya konsentrasi yang tepat untuk setiap stek tanaman akan saling berbeda, dimana oleh Daskalakis et al. (2018) dinyatakan bahwa variabilitas konsentrasi optimum aplikasi IBA sangat ditentukan oleh spesies tanaman. Hasil penelitian yang dilakukan Costa Junior et al. (2018) menunjukkan konsentrasi IBA di atas 2500 ppm dapat menghambat pembentukan akar pada Rosmarinus officinalis dan konsentrasi diatas 1500 ppm merupakan penghambatan pada Aloysia triphylla. Hasil penelitian yang dilakukan Suryo dkk. (2016) menunjukkan pemberian IBA 75 ppm telah 
mampu menghasilkan kemampuan berakar, jumlah dan panjang akar primer; serta jumlah dan panjang akar sekunder yang lebih baik pada stek stek pucuk meranti (Shorea platyclados). Akan tetapi hasil penelitian Amilda dan Petrus (2016) menunjukan pemberian IBA 300 ppm memberikan persen stek hidup, persen stek bertunas, waktu awal bertunas, jumlah tunas, dan panjang tunas tertinggi pada stek Gyrinops verstegii. Penelitian yang dilakukan Erdiansyah et al. (2016) serta Rokhani et al. (2016) menunjukkan pemberian IBA 4500 ppm pada kopi liberika memberikan pertumbuhan akar stek batang terbaik, sementara itu untuk tanaman kopi arabika varietas Caturra menunjukan hasil perakaran terbaik (89\%) dengan penggunaan IBA 2000 ppm (Vallejos-Torres et al., 2020). Namun, pada tanaman kopi robusta menunjukkan penggunaan substansi tumbuh alami yaitu air kelapa dan urin sapi dengan masingmasing konsentrasi $5 \%$ hingga 10\% tidak menunjukkan pengaruh terhadap pertumbuhan akar dan tunas pada stek batang kecuali persentase setek berkalus (Dani et al., 2015). Oleh Babashpour-Asl et al. (2012) dinyatakan tinggi rendahnya konsentrasi IBA dalam menstimulir pembentukan akar pada stek dipengaruhi sifat kekerasan batang dan spesies tanaman, dimana hasil penelitiannya menunjukan pemberian IBA 2000 ppm pada stek batang bersifat semi keras seperti bugenvil menunjukkan pembentukan jumlah akar tertinggi. Contessa et al. (2011) menyatakan secara umum untuk penggunaan IBA pada stek batang tidak diijinkan lebih dari 1000 ppm karena pada konsentrasi lebih dari 1000 ppm menyebabkan kematian pada tunas dan stek. Berdasarkan latar belakang di atas, maka tujuan penelitian adalah menentukan konsentrasi IBA yang terbaik terhadap pertumbuhan akar dan tunas pada stek kopi robusta.

\section{METODE PENELITIAN}

Penelitian dilakukan pada tahun 2017 di Kecamatan Tuntang, Kabupaten Semarang, Provinsi Jawa Tengah. Perlakuan menggunakan tujuh konsentrasi IBA yaitu 0 (kontrol), 50, 100, 150, 200, 250, dan $300 \mathrm{ppm}$. Tata letak perlakuan dengan Rancangan Acak Kelompok (RAK) dan setiap perlakuan diulang 4 kali. Parameter pengamatan adalah panjang akar, jumlah daun dan bobot berangkasan stek kopi. Analisis data menggunakan Analysis of Variance (Anova) dan dilanjutkan Uji Beda Nyata Jujur (BNJ) pada taraf kepercayaan $95 \%$.

Bahan stek dari cabang ortotrop kopi robusta (Klon BP42) dengan umur cabang sekitar 5-6 bulan. Cabang diambil antara ruas 2 dan 3 dari atas dengan panjang 7-10 $\mathrm{cm}$ yang disertai dengan sepasang daun dan 
kemudian dipotong $1 / 2$ bagian. Pemotongan ujung cabang stek dilakukan secara miring dengan sudut $45^{\circ} \mathrm{C}$ (meruncing). Setelah ujung stek dipotong kemudian seluruh stek batang direndam ke dalam IBA sesuai dengan konsentrasi yang telah ditetapkan selama 1 jam. Untuk menjaga agar auksin tidak rusak, selama perendaman seluruh material stek ditutup dengan kain. Setelah perendaman selesai kemudian material stek ditiriskan sekitar 5 menit dalam ruang gelap dan ditanamkan di media tanam dengan jarak tanam antar setek yaitu $10 \times 15 \mathrm{~cm}$. Penanaman stek batang secara vertikal pada media tanam yang telah siap didalam sungkup.

Media tanam menggunakan campuran tanah (top soil), pasir dan pupuk kandang dengan perbandingan 1:1:1. Ketiga media tanam diayak dengan ukuran 5 mesh, dan masing-masing media disterilkan terpisah pada suhu $70^{\circ} \mathrm{C}$ selama 30 menit. Setelah media dingin, semua media dicampur merata sesuai perbandingannya. Media yang telah siap, dimasukkan dalam kotak penanaman stek dengan ukuran tinggi $30 \mathrm{~cm}$ dan lebar 100 $\mathrm{cm}$ dan panjang $200 \mathrm{~cm}$. Penanaman stek dilakukan dalam sungkup (shading house) dengan atap berbentuk setengah lingkaran. Ukuran sungkup dengan lebar $125 \mathrm{~cm}$, tinggi $125 \mathrm{~cm}$ dan panjang $250 \mathrm{~cm}$. Selama proses penyetekan, kondisi iklim mikro dalam sungkup diatur kelembaban udara pada kisaran 90-96\% dengan memberikan kabut air, suhu udara pada kisaran 23 $26^{\circ} \mathrm{C}$ dengan memberikan kipas angin serta tingkat intensitas matahari yang masuk dalam sungkup sekitar $40 \%$ dengan memberikan naungan paranet hitam yang berjarak $1 \mathrm{~m}$ dari atap sungkup.

\section{HASIL DAN PEMBAHASAN}

\section{Rasio C-N Bahan Stek Kopi Robusta}

Kandungan karbohidrat dan protein dalam stek batang akan menentukan keberhasilan tumbuh stek yaitu dalam membentuk akar dan tunas daun. Karbohidrat dan protein akan menentukan proses pertumbuhan akar dan tunas daun pada stek, karena karbohidrat sebagai sumber energi untuk pembelahan dan diferensiasi sel dan protein sebagai komponen utama dalam pembentukan protoplasma sel (Davis et al., 2008). Tabel 1 dibawah adalah nilai perbandingan atau rasio $\mathrm{C} / \mathrm{N}$ yang untuk melihat perbandingan kandungan karbohidrat dan nitrogen dalam stek batang kopi robusta yang digunakan.

Ketidakseimbangan karbohidratprotein dalam stek akan menghambat pertumbuhan dan perkembangan sel, nilai $\mathrm{C} / \mathrm{N}$ rasio yang tinggi akan membantu dan mendorong pembentukan akar (Nurmawati, 2014). Tabel 1 menunjukan semua material stek batang kopi robusta memiliki rasio $\mathrm{C} / \mathrm{N}$ yang relatif sama yaitu berkisar 5,07 - 5,66. Berdsarkan Tabel 1 menunjukkan bahwa 
Tabel 1. Rasio C/N stek batang kopi robusta

\begin{tabular}{cccc}
\hline Konsentrasi IBA $(\mathrm{ppm})$ & $\mathrm{C}-\%$ & $\mathrm{~N}-\%$ & $\mathrm{C}: \mathrm{N}$ \\
\hline 0 & 0,84 & 0,17 & 5,07 \\
50 & 0,77 & 0,15 & 5,09 \\
100 & 0,78 & 0,16 & 5,01 \\
150 & 0,81 & 0,15 & 5,38 \\
200 & 0,91 & 0,16 & 5,66 \\
250 & 0,76 & 0,15 & 5,08 \\
300 & 0,80 & 0,15 & 5,22 \\
\hline
\end{tabular}

meterial stek batang kopi robusta yang digunakan memiliki tingkat keseragaman kandungan karbohodrat dan nitrogen yang baik sehingga pertumbuhan akar dan tunas daun lebih dominan ditentukan oleh perlakuan konsentrasi IBA.

\section{Pengaruh Konsentrasi IBA Terhadap Pertumbuhan Akar Stek Kopi Robusta}

Awal pertumbuhan stek ditandai munculnya kalus pada bagian pelukaan stek. IBA sebagai auksin eksogen memiliki stabilitas kimia yang tinggi dan cenderung akan terakumulasi di lokasi kalus sebelum primordium akar mulai terbentuk (Ditengou et al., 2008). Kalus yang terbentuk akan mengalami diferensiasi sel sehingga nanatinya akar akan terbentuk pada kalus tersebut. Oleh karena itu muncul dan berkembangnya akar pada stek, digunakan indikator pertumbuhan stek batang. Tidak semua stek yang tumbuh kalus akan berkembang menjadi akar, hal ini seperti yang dinyatakan oleh Tajbakhsh et al. (2009) bahwa jumlah dan panjang akar stek yang muncul dari kalus tergantung pada konsentrasi IBA yang diberikan, sehingga tidak semua stek yang berkalus akan menghasilkan akar. Terbentuknya akar pada kalus tersebut harus mengalami pembesaran dan diferensiasi sel yang dipengaruhi beberapa faktor seperti substansi pengatur tumbuh, kesuburan media tanam, kelembaban media tanam, rasio C/N stek (Kastono $d k k$., 2005).

Tabel 2 menunjukan pemberian IBA 150 ppm telah mampu memiliki panjang akar stek kopi robusta secara nyata lebih tinggi dibanding konsentrasi IBA 0 (kontrol) dan IBA $50 \mathrm{ppm}$ tetapi tidak berbeda nyata panjang akarnya jika dibanding IBA 100 ppm 200 dan 250 ppm. Sementara itu pemberian kosentrasi IBA yang lebih tinggi lagi yaitu 300 ppm memiliki panjang akar yang secara nyata lebih rendah dibandingkan perlakuan IBA 150 ppm. Panjang akar meningkat seiring peningkatan konsentrasi IBA hingga pada konsentrasi 150 ppm adalah konsentrasi terbaik. 
Tabel 2. Pengaruh konsentrasi IBA terhadap panjang akar stek kopi robusta

\begin{tabular}{cc}
\hline Konsentrasi IBA $(\mathrm{ppm})$ & Panjang akar stek kopi $(\mathrm{cm})$ \\
\hline 0 & $2,44 \mathrm{a}$ \\
50 & $3,06 \mathrm{a}$ \\
100 & $5,13 \mathrm{ab}$ \\
150 & $7,63 \mathrm{bc}$ \\
200 & $10,06 \mathrm{c}$ \\
250 & $6,56 \mathrm{bc}$ \\
300 & $5,13 \mathrm{ab}$ \\
\hline
\end{tabular}

Keterangan: angka yang diikuti huruf yang sama menunjukkan tidak berbeda nyata antar perlakuan pada uji $\mathrm{BNJ} p=5 \%$.

Oleh Hidayat (2007) dinyatakan adanya interaksi substansi pengatur tumbuh yang ditambahkan dari luar (eksogen) dan yang dihasilkan sel itu sendiri (endogen) mempengaruhi morfogenesis jaringan tanaman. Pemberian IBA 150 ppm telah mampu memberikan interaksi yang baik dengan auksin endogen dalam meningkatkan pertumbuhan akar dibandingkan dengan perlakuan lainnya. IBA adalah auksin eksogen yang stabil dan akan terakumulasi pada bagian kalus, dimana pada konsentrasi yang optimal dari akumulasi auksin pada kalus akan mengoptimalkan pembelahan dan diferensiasi sel menjadi primordia akar, peningkatan konsentrasi yang lebih tinggi dari konsentrasi optimal akan memberikan efek penghambatannya pada pertumbuhan akar (Ali et al., 2009). Oleh Baker dan Wetzstein (2004) telah dilaporkan bahwa konsentrasi auksin yang tinggi akan menginduksi tingkat penguraian senyawa hasil metabolisme dalam jaringan sehingga akan menghalangi proses regenerasi sel dan akibatnya pembentukan dan pertumbuhan akar terhenti. Seperti proses perkembangan sel lainnya, pemanjangan akar berhubungan dengan pertambahan jumlah sel dan pemanjangan ukuran sel oleh adanya aktivitas enzim dimana aktifitas enzim tersebut dipicu oleh auksin (Cosgrove, 1999). Oleh Wada et al. (1998) dinyatakan bahwa IBA mampu meningkatkan panjang akar karena IBA berpengaruh pada sintesis enzim yang terlibat dalam pembesaran sel, sedangkan Muller (2000) melaporkan bahwa IBA mampu mempengaruhi pemanjangan akar adanya peningkatan serapan nutrisi, transport nutrisi dan hasil metabolisme tanaman serta peningkatan metabolisme tanaman. Sementara itu Kollmeier et al. (2000) melaporkan bahwa fase pemanjangan akar sangat sensitif terhadap konsentrasi auksin dan terhambat oleh konsentrasi auksin yang tinggi pada media perakaran. Konsentrasi auksin diatas optimal (tinggi) akan menghambat pemanjangan akar melalui peningkatan biosintesis etilen. Hal ini juga dinyatakan 
oleh Taiz dan Zeiger (2002) bahwa pertumbuhan akar membutuhkan konsentrasi auksin yang optimal dan pertumbuhan akar akan terhambat oleh adanya peningkatan konsentrasi auksin diatas optimal karena adanya peningkatan produksi etilen sehingga pertumbuhan akar terhambat.

Pengaruh Konsentrasi IBA Terhadap Jumlah Daun Stek Kopi Robusta

Pemberian berbagai konsentrasi IBA belum mampu mempengaruhi jumlah daun pada stek batang kopi robusta (Gambar 1). Penggunaan IBA sebagai sumber auksin mempengaruhi pembentukan akar secara dominan, dan setelah akar terbentuk maka peranan akar akan meningkatkan serapan hara dan air untuk pembentukan tunas daun. Akan tetapi dalam pemberian berbagai konsentrasi IBA ini akar yang terbentuk belum mampu meningkatkan jumlah daun. Faktor tumbuhnya jumlah daun pada stek batang dipengaruhi keberadaan auksin, sitokinin, banyaknya buku tunas, serta kandungan $\mathrm{C}$ dan $\mathrm{N}$ pada batang (Samanhudi et al. , 2010; Baskoro dan Purwoko, 2010; Rofiul dan Ari, 2018; Jayanti dkk., 2019; Kurepa et al., 2019). Secara lebih tegas seperti yang dinyatakan oleh Lin et al. (2000) bahwa fungsi auksin akan menginduksi akar sehingga auksin dinyatakan sebagai regulator pertumbuhan efektif untuk rooting, dan oleh Tamba Martino dan Sarman (2019) juga dinyatakan bahwa auksin mempengaruhi pembentukan akar yang lebih cepat dan panjang serta mampu memberikan sistem perakaran yang kuat, kompak dan menyerabut. Bagian ruas batang kopi robusta yang digunakan dengan umur yang sama maka batang stek tersebut memiliki kandungan $\mathrm{C} / \mathrm{N}$ yang sama (Tabel 1 ).

\section{Pengaruh Konsentrasi IBA Terhadap Berat Berangkasan Basah dan Kering Stek Kopi Robusta}

Berat berangkasan basah merupakan indikator pertumbuhan yang berkaitan dengan kandungan air dan karbohidrat dalam jaringan tanaman. Gambar 2 memperlihatkan pemberian konsentrasi IBA belum mampu mempengaruhi berat berangkasan basah dan kering. Kondisi ini terjadi karena terkait dengan jumlah daun (Gambar 1) dimana konsentrasi IBA belum mampu mempengaruhi jumlah daun sehingga berdampak juga pada berat berangkasan basah yang juga tidak mampu ditingkatkan dengan pemberian IBA. 


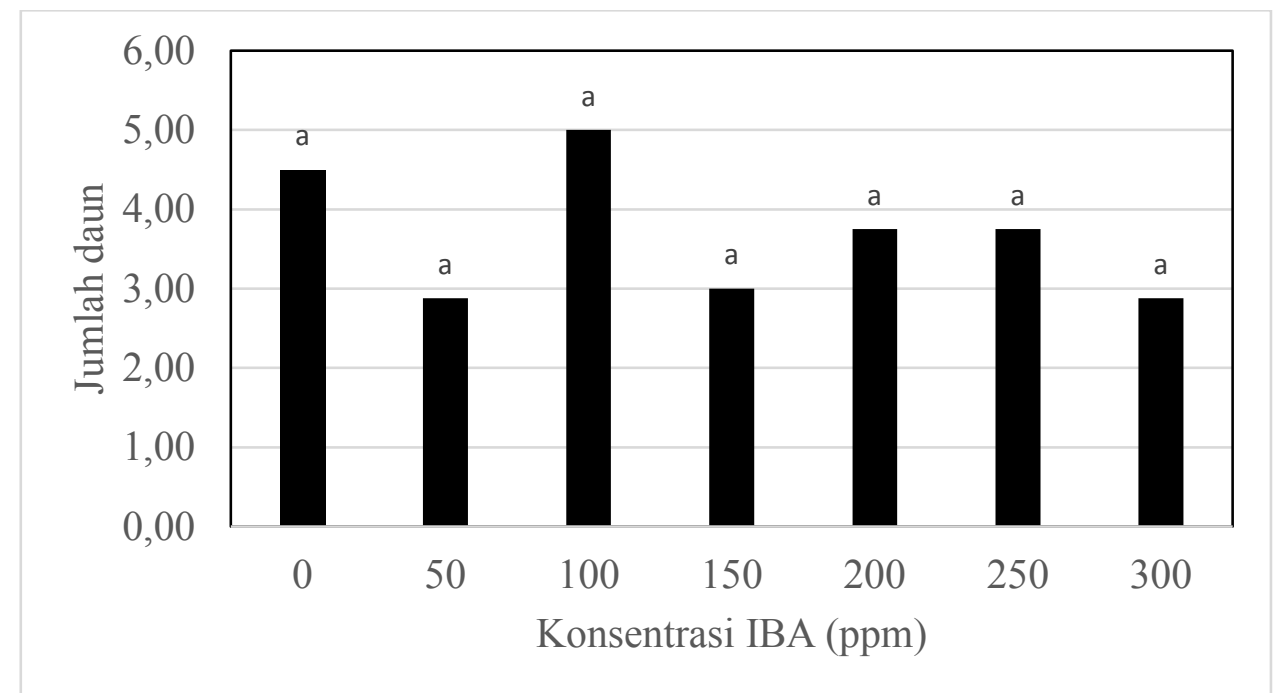

Gambar 1. Pengaruh Konsentrasi IBA terhadap jumlah daun stek kopi robusta

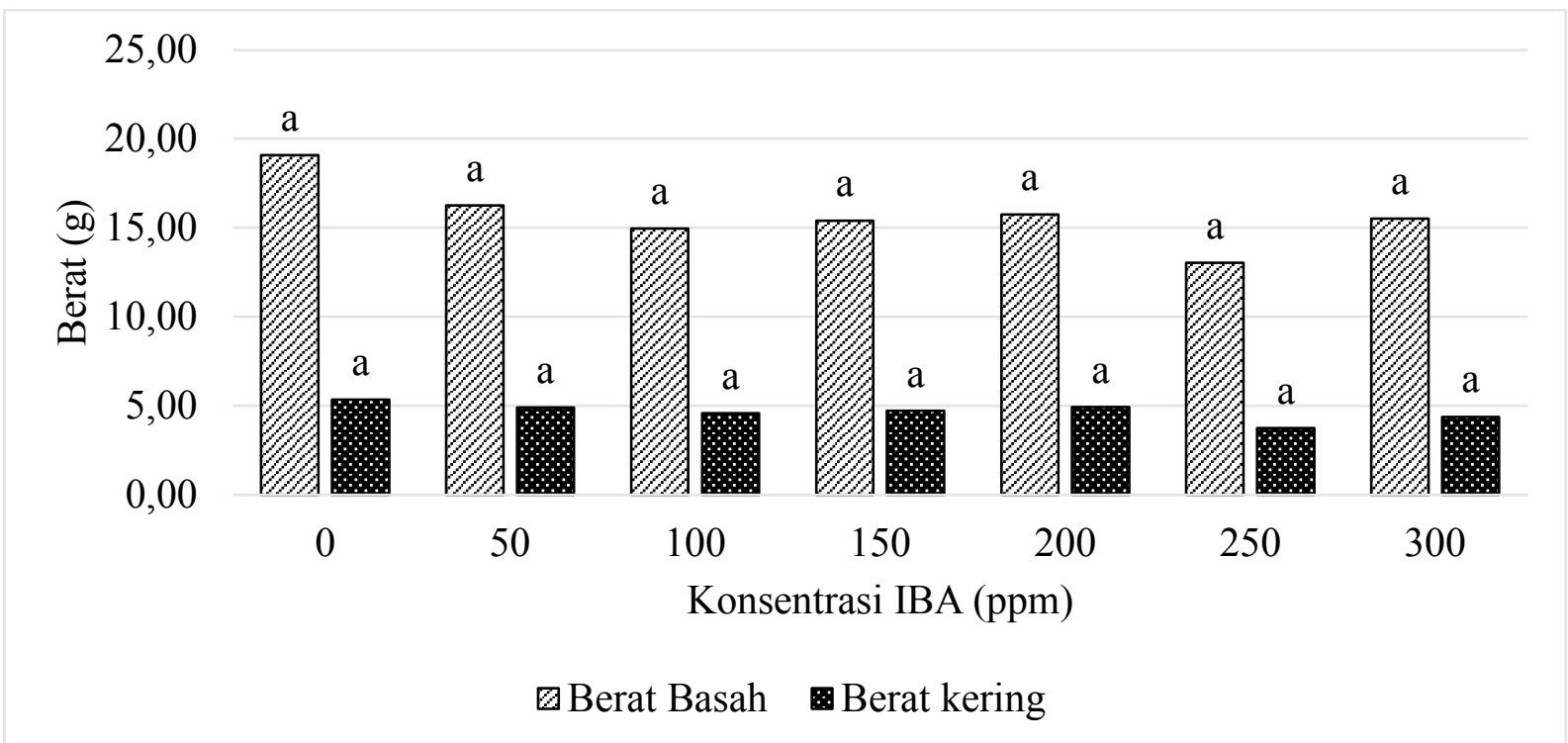

Gambar 2. Pengaruh Konsentrasi IBA terhadap berat berangkasan basah dan kering stek.

Jumlah daun dan luas daun akan menentukan banyaknya fotosintat yang dihasilkan dimana penimbunan fotosintat akan terlihat dari berat berangkasan kering. Berat berangkasan kering adalah hasil penimbunan bersih asimilat sepanjang pertumbuhan tanaman. Berat kering tanaman pada prinsipnya merupakan hasil berat segar tanaman yang dihilangkan kandungan airnya dan pada akhirnya yang tersisa adalah senyawa organik yang dalam bentuk biomassa. Peningkatan berat kering melalui peningkatan hasil fotosintesa disebabkan oleh terpenuhinya kebutuhan tanaman seperti air dan unsur hara. Tanaman yang memiliki laju fotosintesis tinggi mampu menghasilkan fotosintat dalam jumlah besar. Stek yang memiliki jumlah daun sama maka akan memiliki laju fotosintesis yang sama sehingga berat berangkasan basah dan kering stek akan sama juga. 
Penggunaan IBA pada stek kopi robusta memberikan respon yang berbeda terhadap setiap pertumbuhan organ tanaman. Hal ini tampak pada pemberian IBA 150 ppm telah mampu memberikan panjang akar terbaik dibandingkan perlakuan lainnya (Tabel 2). Pembentukan akar pada stek ditentukan dari muncul dan tumbuhnya sel kalus pada bagian pelukaan stek. Kalus merupakan jaringan yang belum terorganisir sebagai respon tumbuhan untuk menutupi luka (Purba dan Astawa, 2017). Sel pada kalus akan mengalami pembesaran dan diferensiasi hingga akhirnya akan membentuk akar, dan salah satu faktor penentu pembentukan akar tersebut adalah keberadaan auksin. Oleh Gustini (2013) dinyatakan auksin yang ada pada tanaman akan merangsang pertumbuhan akar pada kalus. Keberadaan auksin eksogen seperti IBA akan menstimulir stek dalam pembentukan dan pertumbuhan akar. IBA sebagai sumber auksin dari luar (eksogen) dapat menunjang aktivitas auksin yang ada dalam stek, sehingga adanya peningkatan auksin dalam jaringan stek batang akan mempercepat proses diferensiasi sel membentuk sel baru (Adinugraha et al., 2006) dan akibatnya proses pembentukan akar di kalus akan lebih dipacu. Namun terjadi sebaliknya bahwa pemberian IBA belum mampu meningkatkan jumlah daun. Hal ini dikarenakan munculnya jumlah daun bukan semata ditentukan oleh auksin akan tetapi oleh rasio auksin-sitokinin, rasio C-N stek batang dan banyaknya buku tunas. Oleh karena jumlah daun yang tidak mampu ditingkatkan oleh IBA maka juga berpengaruh pada berat berangksan basah dan kering tanaman juga tidak mampu ditingkatkan oleh pemberian IBA. Stek yang memiliki jumlah daun sama maka akan memiliki laju fotosintesis yang sama sehingga berat berangkasan basah dan kering stek akan sama juga.

\section{KESIMPULAN}

Pemberian IBA 150 ppm pada stek batang kopi robusta mampu menghasilkan panjang akar terbaik. Namun demikian, berbagai konsentrasi IBA yang dicobakan belum mampu meningkatkan jumlah daun, berat berangkasan basah, dan berat berangkasan kering stek batang kopi robusta.

\section{DAFTAR PUSTAKA}

Adinugraha H.A, Moko H., Cepi. 2006. Pertumbuhan stek pucuk sukun asal dari populasi Nusa Tenggara Barat dengan aplikasi zat pengatur tumbuh. Jurnal Penelitian Hutan Tanaman, 3 (2): 93-99.

Amilda Auri dan Petrus A. Dimara. 2016. Respon pertumbuhan stek Gyrinops verstegii terhadap pemberian berbagai tingkat konsentrasi hormon IBA (Indole Butyric Acid). Jurnal Silvikultur Tropika, 06 (2):133-136.

Akram M.T., Qadri R.W.K., Khan I, Bashir M, Jahangir M.M., Nisar N., Khan M.M. 2017. Clonal multiplication of 
guava (Psidium guajava) through soft wood cuttings using IBA under lowplastic tunnel. International Journal of Agriculture and Biology, 19(3): 417422.

Akwatulira F., Gwali S., Okullo J.B.L., Ssegawa P., Tumwebaze S.B., Mbwambo J.R., Muchugi A. 2011. Influence of rooting media and indole-3-butyric acid (IBA) concentration on rooting and shoot formation of Warburgia ugandensis stem cuttings. African J. Plant Sci., 5 (8): 421-429.

Ali A., Ahmad T., Abbasi N.A., Hafiz I.A. 2009. Effect of different concentrations of auxins on In vitro rooting of olive cultivar Moraiolo. Pakistan J. Bot., 41 (3): 1223-1231.

Babashpour-Asl M., Shakueefar, S., Valipour, V. 2012. Effects of indole3-butyric acid on the rooting ability of semi-hardwood Bougainvillea sp. cuttings. Mo. Appl. Sci., 6(5), 121123.

Baker C.M. and H.Y. Wetzstein. 2004. Influence of auxin type and concentration on peanut somatic embryogenesis. Pl. Cell Tissue Organ Cult., 36(3): 361-368.

Baskoro D. dan B. S. Purwoko. 2010. Pengaruh bahan perbanyakan tanaman dan jenis pupuk organik terhadap pertumbuhan tanaman Binahong (Anredera cordifolia (Ten.) Steenis). J. Hort. Indonesia, 2(1) : 613.

Blythe E.K., Sibley J.L., Tilt K.M., Ruter J.M. 2007. Methods of auxin application in cutting propagation: a review of 70 years of scientific discovery and commercial practice. J. Environ. Hortic., 25(3): 166-185.

Brata I.K., Sutedja I.N., Arimbawa I.W.P. 2020. Pertumbuhan setek Kopi Robusta (Coffea canephora P.) yang dirangsang dengan Urin Sapi, Air
Kelapa dan Atonik dengan berbagai taraf kosentrasi. J. Agroekoteknologi Trop., 9 (1): 1-11.

Contessa C., N. Valentini, R. Botta. 2011. Decreasing the concentration of IBA or combination with etylen Inhibitors Improve bud retention in semihardwood cutting of Hazenut cultivar 'Tonda Gentile delle Langhe'. Scientia Horticulturae, 131: 103-106.

Cosgrove D.J. 1999. Enzymes and other agents that enhance cell wall extensibility. Crit. Rev. P1. Physiol. P1. Mol. Biol., 50: 391-417.

Costa Junior E.D.S., Barbosa M.S.D.M., Silva C.M.A.D., Silva R.C.S.D., Kiill L.H.P., Beckmann-Cavalcante M.Z. 2018. Vegetative propagation of Rhaphiodon echinus Schauer (Lamiaceae): effects of the period of cutting in rooting, cuttings arrangement and IBA concentrations for seedlings production. Ornamental Horticulture, 24(3): 238-247.

Dani Sulistiyorini I., Tresniawati C., Rubiyo. 2015. Keragaman pertumbuhan setek satu ruas enam klon Kopi Robusta yang diperlakukan dengan hormon tumbuh alami. Sirinov, 3(1): 49-54.

Daskalakis I., Biniari K., Bouza D., Stavrakaki M. 2018. The effect that indolebutyric acid (IBA) and position of cane segment have on the rooting of cuttings from grapevine rootstocks and from Cabernet franc (Vitis vinifera L.) under conditions of a hydroponic culture system. Sci. Hortic., 227: 79-84.

Davis T.D., B.E.Haissig dan N. Sankhia. 2008. Adventitious root formating in Cutting. Advances in Plant Species. Vol 2. Dioscorides Press. Portland,Oregon. USA.

Dewi P.S., Susanti D. 2010. Pengaruh Kinetin terhadap inisiasi dan pertumbuhan tunas perbanyakan 
tanaman Jarak Pagar (Jatropha curcas L) secara in vitro. Agrin, 14(1): 29-36.

Ditengou F.A., Teale W.D., Kochersperger P., Flittner K.A., Kneuper I., Van Der Graaff E., Nziengui H., Pinosa F., Li X., Nitschke R., Laux T., Palme K. 2008. Mechanical induction of lateral root initiation in Arabidopsis thaliana. Proc. Natl. Acad. Sci. U. S. A., 105(48): 18818-18823.

Erdiansyah N.P., Rokhani I.P., Waluyo S. 2016. Cutting wood origin and Indole Butyric Acid influence success of liberica coffee cuttings (Coffea Liberica W. Bull Ex. Hier). Pelita Perkeb. (a Coffee Cocoa Res. Journal), 32(3): 198-205.

Geiss G., Gutierrez, L., C. Bellini. 2009. Adventitious root formation: New insights and perspectives. Annu. Plant Rev., 37: 127-156.

Gilani S.A.Q., Shah K., Ahmed I., Basit A., Sajid M., Bano A.S., Shahid U. 2019. Influence of indole butyric acid (IBA) concentrations on air layerage in guava (Psidium guajava L.) cv. Sufeda. Pure and Applied Biology, 8(1): 355-362.

Gudeva L.K., Trajkova F., Mihajlov L., Troicki J. 2017. Influence of different auxins on rooting of rosemary, sage and elderberry. Annu. Res. Rev. Biol., 12(5): 1-8.

Gustini D. 2013. Pengaruh rootone F dan pemberian bayfolan terhadap pembentukan akar dan pertumbuhan salak. Biospecies, 6(2): 8-13.

Hadiati S. 2011. Pengaruh konsentrasi BAP terhadap pertumbuhan stek batang Nenas (Ananas comosus L). Jurnal Agrin Penelit. Pertan., 15(2): 127132.

Hidayat. 2007. Induksi pertumbuhan eksplan endosperm ulin dengan IAA dan Kinetin. Agritop, 26(4): 147-152.
Kastono D., H. Sawitri, dan Siswandono. 2005. Pengaruh nomor ruas stek dan dosis pupuk urea terhadap pertumbuhan dan hasil kumis kucing. Ilmu Pertanian, 12(1): 56-64.

Kesari V., Das A., Rangan L. 2010. Effect of genotype and auxin treatments on rooting response in stem cuttings of CPTs of Pongamia pinnata, a potential biodiesel legume crop. Curr. Sci., 98(9): 1234-1237.

Khasin M., Cahoon R.R., Nickerson K.W., Riekhof W.R. 2018. Molecular machinery of auxin synthesis, secretion, and perception in the unicellular chlorophyte alga Chlorella sorokiniana UTEX 1230. PLoS One, 13(12): 1-13.

Kollmeier M, H.H. Felle and W.J. Horst. 2000. Is basipetal auxin flow involved in inhibition of root elongation. Pl. Physiol., 122: 945-956.

Kurepa J., Shull T.E., Smalle J.A. 2019. Antagonistic activity of auxin and cytokinin in shoot and root organs. Plant Direct, 3(2): e00121.

Lin H.S., M.J. De Jue and E. Jacobsen. 2000. Plant tissue culture. Science Horticulturae, 85(6): 307-318.

Li X, Suzuki T., Sasakawa H. 2009. Promotion of root elongation and ion uptake in rice seedlings by $4,4,4-$ trifluoro-3-(indole-3-) butyric acid. Soil Science and Plant Nutrition, 55(3): 385-393.

Mejury S., Ruvimbo M.M., Marjory T., Collen M., Tsvakai G. 2019. Effects of rooting media and indole-3-butyric acid (IBA) concentration on rooting and shoot development of Duranta erecta tip cuttings. African J. Plant Sci., 13(10): 279-285.

Mohammad G., Mohammad, A.K., Sayed, R.M. 2013. Effects of different auxin (IBA) concentrations and plantingbeds on rooting grape cuttings (Vitis 
vinifera). Annu. Res. Rev. Biol., 3 (4), 517-523.

Muller J.L. 2000. Indole-3-butyric acid in plant growth and development. $\mathrm{Pl}$. Growth Reg.,32(2-3): 219-230.

Ningsih E.P., Rohmawati I. 2019. Respon stek pucuk tanaman Miana (Coleus atropurpureus (L.) Benth) terhadap pemberian zat pengatur tumbuh. J. Biol. Trop., 19(2): 277-281.

Nurmawati Siregar. 2014. Pengaruh umur bahan setek terhadap pertumbuhan setek Akor (Acaciaauri culiformis A. Cunn. Ex Benth). Jurnal Perbenihan Tanaman Hutan, 2(2): 109-117.

Pacurar D.I, Perrone I., Bellini C. 2014. Auxin is a central player in the hormone cross-talks that control adventitious rooting. Physiologia Plantarum, 151(1): 83-96.

Pandey A., Tamta S., Giri D. 2011. Role of auxin on adventitious root formation and subsequent growth of cutting raised plantlets of Ginkgo. Int. J. Biodivers. Conserv., 3(4): 142-146.

Pop T.I., Pamfil D., Bellini C. 2011. Auxin control in the formation of adventitious roots. Not. Bot. Horti Agrobot. Cluj-Napoca, 39(1): 307316.

Purba R.V., Astawa I.N.G. 2017. Induksi kalus eksplan daun tanaman Anggur (Vitis vinivera $\mathrm{L}$. ) dengan aplikasi 2,4-D secara in vitro. E-Jurnal Agroekoteknologi Trop., 6(2): 218228

Rokhani I.P., Waluyo S., Erdiansyah N.P. 2016. Pertumbuhan stek kopi Liberika (Coffea liberica W. Bull Ex. Hier) pada tiga bahan stek dan empat konsentrasi IBA. Vegetalika, 5(2): $28-48$

Rofiul, A. dan Ari, H. 2018. Pengaruh macam zat pengatur tumbuh alami terhadap pertumbuhan stek beberapa klon kopi robusta (Coffea canephora). Biofarm, 14(2): 71-81.

Samanhudi E. S. Muliawati, dan E. Setyorani. 2010. Kajian frekuensi pemberian air dan macam pupuk organik terhadap pertumbuhan dan hasil tanaman kumis kucing. J. Ilmiah Pertanian, 13(8) : 70-85.

San Jose M.C., Romero, L., Janeiro, L.V. 2012. Effect of indole-3-butyric acid on root formation in 193 Alnus glutinosa microcuttings. Silva Fenn., 46(5): 643-654.

Saptaji, Setyono, Rochman N. 2015. Pengaruh air kelapa dan media tanam terhadap pertumbuhan stek Stevia (Stevia rebaudiana Bertoni). J. Agronida, 1(2): 83-91.

Skupa P., Opatrny Z., Petrasek J. 2014. Auxin Biology: Application and the mechanisms behind. In: Applied Plant Cell Biology, Plant Cell Monographs (Ed. Opatrny P.N. and Z.). Springer-Verlag Berlin Heidelberg, Czech Republic: 69-102.

Suryo Hardiwinoto, Rixa Riyanti, Widiyatno, Adriana, Widaryanti Wahyu Winarni, Handojo Hadi Nurjanto, dan Eko Priyo. 2016. Percepatan kemampuan berakar dan perkembangan akar stek pucuk Shorea platyclados melalui aplikasi zat pengatur tumbuh IBA. Jurnal Pemuliaan Tanaman Hutan, 10(2): 63-70.

Syafarudin, Dani, Pabendon M.B. 2017. Keragaman genetik antar klon kopi robusta lokal Pagar Alam berdasarkan analisis marka SSR. J. Tanam. Ind. dan Penyegar, 4(3): 133-134.

Tajbakhsh M., Korkan M., Ghiyasi M. 2009. Efect of timing on callus formation and rooting ability in IBAtreated hardwood stem cuttings of persian walnut, hazelnut and apple. Not. Bot. Horti Agrobot. ClujNapoca, 37(1): 103-107. 
Tamba R.A.S., Martino D., Sarman. 2019. Pengaruh pemberian auksin (NAA) terhadap pertumbuhan tunas tajuk dan tunas cabang akar bibit karet (Hevea brasillensis Muell. Arg) okulasi mata tidur. Agroecotenia, 2(2): 11-20.

Taiz L. and E. Zeiger. 2002. Mineral nutrition: Plant physiology. 2nd ed. Sinaver Associates Inc. Pub.: 67-86.

Vallejos-Torres G., Arevalo L.A., Rios O., Cerna A., Marin C. 2020. Propagation of rust-tolerant coffea arabica L. plants by sprout rooting in microtunnels. Journal of Soil Science and Plant Nutrition, 20: 933-940.
Wada S., E. Tanimoto and Y. Masuda. 1998. Cell elongation and metabolic turnover of the cell wall as affected by auxin and cell wall degrading enzymes. Pl. Cell Physiol., 9(2): 369376.

Widaningsih R., 2019. Outlook kopi. Kementerian Pertanian. Jakarta

Yulianto A.G., E. Setiawan dan K. Badami. 2015. Efek pemberian IBA terhadap pertautan sambung samping tanaman srikaya. Agrovigor, 8(2): 51-56. 